\title{
THE CUSTOMS UNION: A FINAL STEP BEFORE TURKEY'S ACCESSION TO THE EUROPEAN UNION?*
}

\author{
Halûk A. KABAALjOĞLU**
}

\begin{abstract}
The Ankara Agreement, establishing an association between Turkey and the $E C$, envisions the customs union as a step towards a fuller integration. Nevertheless, Turkey did not appear on the list of candidate countries whose accession is being considered in the forthcoming accession negotiations. The Article explains the reasons as to why a customs union was achieved and the ways it is implemented as well as the contents and the institutional aspects of this unique relationship. The author believes that the customs union is not a permanent stage and disintegration may occur unless the two sides proceed to further integration.
\end{abstract}

\section{Introduction}

In 1996 Turkey has completed the customs union process with the European Community in accordance with her Association Agreement. Thus, integration of Turkey into the internal Market is almost complete and Turkey has a most intimate relationship with the European Union. The completion of the customs union constitutes a final phase of Turkish association before accession to the Community in accordance with the agreement. The attitude of the European Union towards Turkey however -a NATO country for the last forty-five years, defending Western Europe against the Warsaw Pact- puzzles many Europeans in Turkey when countries like Bulgaria are mentioned as candidates but Turkey is omitted.

- This is a revised version of the Arlicle tilled The Turkish Model of Association: Customs Union Beiore Accession" published in P. Demaret, J.F. Bellis and G.G. Jimenez (eds.) Regionalism and Multilateralism after the Uruguay Round: Convergence, Divergence and Interaction, European Interuniversity Press, Brussels, 1997, pp. 115-160.

* Professor of EU Law; Chairman of TUNAECS (Turkish Universities Association for the EC Studles) and founding Director of the EC Institute, Marmara University. 
All the Member States and the institutions of the European Union face a historical decision with very serious consequences: will Turkey be denied membership on the grounds of her religios credentials thus making Europe a Christian club or will she be admitted to allay the fears (albeit with long transitional periods in areas like free movement of workers) of some Member States in accordance with the Association Agreement of 1963 where full membership was promised?

With the election results of December 1995, whereby the right of center vote was divided almost equally between three political parties but making an islamist Party the leading political force with a slight $21 \%$, the country's political process entered into a sensitive period in the same year that Turkey completes a customs union with the European Community. Needless to say, the success of the customs union depends on support being provided by the Community. Unfortunately, the EC has not fulfilled her obligations towards Turkey and Turkey remains the only country in the world to have had no financial cooperation with the EC since 1980. Thus, in the Turkish case, the EU expects integration without fulfiling her obligations to Turkey, like the blockage of the Financial Protocols. In order to avoid this, Member States could join forces outside the Community framework to support the customs union process.

Furthermore, the European Union's decision to open negotiations with the Greek Cypriot Administration for accession before a settlement on the island, six months after the completion of the Intergovernmental Conference, totally disregards the Treaties of Guarantee and the Constitution of the island where both the Greek and Turkish communities were established as equal partners in a functional federation.

\section{A. The Establishment of the Customs Union}

\section{Why a Customs Union?}

On January 1, 1996, the customs union between the European Community and Turkey came into effect, thereby creating the closest possible economic and political relationship between the EU and any non-member country.

In setting the objective of a customs union, both Turkey and the Community were much influenced by the success of the customs union then being realized between the six original members of the Community. Both Turkey and the Community looked for similar benefits from the establishment of a customs union between themselves. In fact, if the final aim was to be Turkey's accession, then it was natural that the foundation of this link was going to be the acceptance of all the basic freedoms of movement. Free movement of goods was going to be established by the customs un- 
ion. The Additional Protocol also contained a number of detailed provisions for the implementation of the free movement of workers, services and capital in accordance with the Association Agreement.

The Association Agreement clearly outlined that "in order to attain the objectives set out [in the agreement] a customs union shall be progressively established." What were the objectives referred to in the agreement? The answer to this question can be found in Article 2: "The aim of this agreement is to promote the continuous and balanced strengthening of trade and economic relations between the Parties, while taking full account of the need to ensure an accelerated development of the Turkish economy and to improve the level of employment and living conditions of the Turkish people."

The drafters of these agreements realized that the liberalization of trade would entail sometimes painful adaptations. In order to counterbalance the negative effects of such adaptations, financial protocols were devised together with the introduction of provisions concerning free movement of workers, services and capital.

The discussions of the last few months have given the impression that establishment of a customs union had been agreed in 1995. In lact, this was not the case. Whilst the commitment to establish a customs union was provided in the Association Agreement, its programme, timetables and rules were established in the Additional Protocol. Thus it was all agreed in 1963 and 1970. Some even argued that Turkey's implementation of this programme and adoption of the Common Customs Taritf would be sufficient for the completion of the second stage, as the timetable for the completion of the customs union was determined in the Additional Protocol of 1970.

\section{How was the Customs Union to be Realized?}

Whilst the commitment to establish a customs union was provided in the Association Agreement, it was the Additional Protocol of 1970 which specified the programme for bringing it into being. The 1970 Protocol contained timetables for removing barriers on trade between the partners and the timetables whereby Turkey would adopt the EC's Common Customs Tariff on its trade with third countries.

Article 9 of the Additional Protocol provided that, on the entry into force of this protocol, the Community would abolish customs duties and charges having equivalent effect on Turkish industrial exports to the EC'. 
In addition to the removal of customs duties, all quantitative restrictions on industrial imports into the Community from Turkey were to be abolished by Article 24: "The Community shall on the entry into force of this protocol, abolish all quantitative restrictions on imports from Turkey. Thus liberalization shall be consolidated in respect of Turkey." The consolidation of this liberalization meant that the Community undertook not to reintroduce any of these restrictions ${ }^{2}$.

The abolition of all tariff restrictions on Turkish industrial exports to the Community took effect immediately when the Interim Agreement entered into force on September 1, 1971. With this move, the Community moved almost all the way to achieving a customs union for industrial products in one step at the beginning of the second stage, namely the transitional period.

\section{Turkey's Implementation of the Customs Union}

To establish a customs union both Turkey and the EC had to eliminate tariffs and quantitative restrictions on their trade with one another and adopt a common tariff on imports from third countries. The Additional Protocol provided that both Turkey and the EC should refrain from introducing new import duties on their trade with each other.

The Additional Protocol provided a timetable for Turkey to abolish the existing Turkish tariffs on industrial imports from the EC. Articles 10 and 11 established two different lisis of goods. For industrial sectors in which Turkey was more competitive, tariffs were to be eliminated over a period of twelve years. For other goods, the tariff reductions were to be spread over twenty-two years.

Charges having equivalent effect to customs duties were also to be reduced according to similar timetables. Within twenty-two years, Turkey was to abolish progressively all quantitative restrictions and measures having equivalent effect on imports from the Community (Art. 25).

Adoption by Turkey of the Common Customs Tarift (CCT) of the EC was provided in Articles 17 and 18 which laid down the timetables by which Turkey was to move towards the CCT of the Community. This alignment was to be completed within twelve and twenty-two years for goods appearing in respective lists.

The goal of the Association Agreement is a customs union, both for industrial and agricultural trade. According to Article 11, "The Association shall likewise extend to agriculture and trade in agricultural products" taking into account the Common Agricultural Policy (CAP) of the Community. It was realized that to implement a customs 
union for agricultural products without first aligning the pricing policies of the EC would cause distortion in agricultural trade. Hence, in the Additional Protocol, Turkey committed herself to adapt her agricultural policy to the CAP during the transitional period to prepare the way for the free movement of agricultural products (Art. 34).

\section{Final Stage in the Pre-accession Period: Customs Union}

Decision No. 1/95 of the Association Council on March 6, 1995 -which refers to the final aim of the agreement being "the accession of Turkey to the Community" (Art. 28) as provided in the preamble: "determined to establish ever closer bonds between Turkish people and the peoples brought together in the EEC"-, noted the following in its preamble: "Considering that the objectives set out by the Ankara Agreement and in particular by its Article 28 , which established the Association between Turkey and the Community, maintain their significance at this time of great political and economic transformation on the European scene; ...", further, "considering that the customs union represents an important qualitative step, in political and economic terms, within the Association relations between the Parties."

The Association Council decided that the third and final phase of the Association which is based on a customs union was to commence as of January 1st, 1996 in accordance with the Association Agreement and the Additional Protocol. Since this was an Association Council Decision for the implementation of the Association Agreement (1963) and Additional Protocol (1970), both of which were duly ratified by the parliaments of all the Member States and entered into froce, thereby being "an integral part of the Community legal system", it was believed that the assent procedure of the European Parliament was not required as this was not a new international agreement but simply an implementation measure of an Association Agreement already in force. In any case the Association Council Decision 1/95 of March 6, 1995 received the assent of the European Parliament with an overwhelming majority when it was decided that the Association Council Decision should be submitted under the assent procedure.

The Association Council Decision 1/95 "lays down the rules for implementing the final phase of the customs union" which was foreseen in the Ankara Agreement.

\section{B. The Content of Decision 1/95 Establishing the EEC-Turkey Customs Union}

\section{Free Circulation of Goods}

The first and second subparagraphs of Article 3 of the Council Decision 1/95 is actually taken from Article $2 \S 1$ and 2 of the Additional Protocol of 1970 which was 
based on Article $10 \S 1$ of the Treaty of Rome. This must be considered only normal as "the Community" is "based upon a customs union" (Art. 9 of the Treaty of Rome). Thereby, the third stage of the Turkish Association which is also "based upon a customs union" adopted the same provisions.

Accordingly the customs union shall apply to the following goods :

- goods produced in the Community or Turkey (including those wholly or partially obtained or produced from products coming from third countries which are in free circulation in the Community or in Turkey),

- goods coming from third countries and in free circulation in the Community or in Turkey.

Since a customs union has been formed, Article $10 \S 1$ of the Treaty of Rome, which was implanted in Article $2 \S 1$ of the Additional Protocol, is also reproduced in Article $3 \S 2$ of the Association Council Decision: "Products from third countries shall be considered to be in free circulation in the Community or in Turkey if the import formalities have been complied with and any customs duties or charges having equivalent effect which are payable have been levied in the Community or in Turkey, and if they have not benefited from a total or partial reimbursement of such duties or charges."

The "customs territory" of the customs union comprises the customs territory of the EC and the customs territory of Turkey (Art. $3 \S 3$ ).

Article 4 on the "Elimination of customs duties and charges having equivalent effect" provides that "import or export customs duties and charges having equivalent effect shall be wholly abolished between the Community and Turkey on the date of entry into force of this Decision (1.1.1996)".

Some other articles in the Decision are simply the repetitions of the corresponding ones in the Additional Protocol which were copied from the Treaty of Rome ${ }^{3}$.

3 Article 12 of the Treaty of Rome which was transplanted into Article 7 of the Additional Protocol of 1970 was again repeated in the Association Council Decision Article 4: "The Community and Turkey shall refrain from introducing any new customs duties on imports or exports or any charges having equivalent effect from that date."

Article 30 of the Treaty of Rome entilled "Elimination of Quantitative Restrictions Between Member States" is Article 21 of the Additional Prolocol and Article 5 of the Council Decision: "Quantitative restrictions on imports and other measures having equivalent effect shall be prohibited between the Contracting Parties".

Article 7 of the Council Decision is another verbatim adoption of a Treaty of Rome provision, that is to say Article 36 on derogations on the grounds of "public morality, public policy or public security; ............" which was already adopted in Article 29 of the Additional Prolocol in 1970 and was simply repeated in the Decision. 


\section{Commercial Policy and Common Customs Tariff}

In 1995, Turkey's Official Journal (Resmi Gazete) published thousands of pages of Turkish legislation based on EC texts.

Furthermore, Turkey aligned her customs tariff with the Common Customs Tariff in relation to countries which are not members of the Community (Art. 13).

Adopting the Common Customs Tariff and all the relevant customs legislation is not sufficient for the completion of the customs union. The commercial policy of Turkey will also have to be harmonized with the common commercial policy of the Community. This involves both the autonomous regimes and preferential agreements with third countries. In order to harmonize Turkish commercial policy with that of the EC, Turkey will negotiate agreements on "a mutually advantageous basis" with the countries concerned. Since this will naturally take some time, Article 16 of Decision $1 / 95$ stipulates that Turkey will align itself "progressively with the preferential customs regime of the Community" within five years as from January 1, $1996^{6}$.

4 Turkey adopted the following Community regulations on commercial policy:

Council Regulation (EC) No. 3285/94 on common rules for imports;

Council Regulation (EC) No. $519 / 94$ on common rules for imports from certain third countries;

Council Regulation (EC) No. $520 / 94$ establishing a Community procedure for administering quantitative quotas (implementing provisions: Commission Regulation (EC) No. 738/94);

Council Regulations (EEC) No. 3283/94, (EC) No. 3284/94 and (EC) No. $522 / 94$ on protection against dumped or subsidised imports;

Council Regulations (EEC) No. 3286/94 on the New Commercial Policy instrument;

Council Regulation (EEC) No. 2603/68 establishing common rules for exports;

Council Decision 93/112/EEC on officially supported export credits;

Council Regulation (EEC) No. 3036/94 and Commission Regulation (EEC) No. 1828/83 on outward processing arrangements for textiles and clothing;

Council Regulation (EEC) No. 3030/93 as last amended by Commission Regulation (EC) No. 195/ 94 on textile imports under common rules;

Council Regulation (EC) No. 517/94 on textile imporls under autonomous arrangements;

Council Regulation (EC) No. $3951 / 92$ as last amended by Council Regulation (EC) No. 217/94 on textile imports from Taiwan.

5 Although Turkey has adopled the Common Customs Tariff of the Community as of January 1 , 1996, for a limited number of products (like motor gasoline, petroleum ether, gas oils, diesel, fuel oil, trunks, suitcases, bags, sacks, kraft paper, footwear, porcelain, china, midibus, minibus, motor vehicles, motor cars, lorries) she has retained customs duties higher than the CCT until January 1st, 2001 in respect of third countries. Decision 2/95, March 6, 1996.

6 The autonomous regimes referred to above cover the General System of Preferences (GSP), the regime for goods originating in the Occupied Terrilories, Ceuta or Melilla, Republics of BosniaHerzegovina, Croatia, Slovenia and Macedonia.

The preferential agreements include: The Europe Agreements with Bulgaria. Hungary, Poland, Romania, Slovakia and the Czech Republic, Free Trade Agreernents with Switzerland, Liechtenstein, Estonia, Latvia, Lithuania and the Faroe Islands, Agreements with Egypt, Jordan, Lebanon. Syria, Algeria, Morocco. Tunisia and Israel and an Association Agreement with Malta. Since the Greek Cypriot Administration in Southern Cyprus is not recognized by Turkey, as the said regime is unconstitutional under the 1960 Constitution and Treaties of Guarantee which brought independence 10 Cyprus, there will not be an agreement with the said entity until a settlement is reached on the island.

The EU decision to open negotiations with the Greek Cypriot Administration six months after the completion of the intergovernmental Conference was an unfortunate move which encouraged the Greek Cypriot side to leave the inter-communal talks. The international treaties forming the Republic and the Constitution of 1960 prevent such a membership. 
Since January 1, 1996 (Art. 12 §), Turkey has applied substantially the same commercial policy as the Community in the textile sector (including the agreement or arrangements on trade in textiles and clothing).

Turkey and the Community made arrangements in order to prevent the circumvention of the Japan-EC Motor Vehicles Agreement relating to trade in motor vehicles mentioned in the annex of the agreement on safeguards attached to the agreement setting up the World Trade Organization.

\section{Customs Provisions}

As the customs union meant not only the elimination of customs duties, quantitative restrictions and measures having equivalent effect but also the alignment of the Turkish Customs Tariffs to the Common Customs Tariff of the Community, it was only natural that Turkey had to adopt legislation in line with the Community Customs Code in the following fields:

Origin of goods; customs value for goods; introduction of goods into the territory of the customs union; customs declaration; release for free circulation; suspensive arrangements and customs procedures with economic impact; movement of goods; customs debt and the right of appeal. (Art. 28)

The Turkish customs legislation already in force, mainly the Customs Law (Gümrük Kanunu) of 1970 (No. 1615) and all the regulations and bylaws adopted thereunder, were, to a great extent, based on the same international customs agreements and further amended over the years in conformity with the EC requirements. Therefore, the legislation in force was very similar to the Community Customs Code. Although a new law was drafted with over 250 articles, which was to cover all the subjects already regulated in various different texts in one Code in a systematic order, due to the heavy parliamentary schedule it has not been adopted so far. For this reason, a series of regulations, decrees and bylaws were published in order to complete the existing legislation. The customs legislation will, of course, be clarified with the adoption of the Draft Law.

In addition to the above-mentioned fields and Community Customs Code (based on Council Regulation (EEC) No. 2913/92 of October 12, 1992) and the Commission Regulation laying down the implementing provisions (No. 2454 of July 2 , 1993), Turkey has adopted a series of texts to implement the following Community legislation.

Needless to say, mutual assistance and cooperation of the administrative authorities both in Turkey and in the Community will be extremely important for the successful implementation of the customs union. Indeed, the Parties shall assist each 
other"... in ensuring that customs legislation is correctly applied, in particular by the prevention, detection and investigation of operations in breach of that legislation" (Art. $2 \S 1$ of the Annex 7 on Mutual Assistance).

Whenever the Common Customs Tariff is changed, Turkey shall adjust its customs tariff to these changes. Below, the institutional framework of the association and the procedure for consultation and decision-making will be analyzed in detail. Suffice it to say that Turkey will be informed about the following decisions in sufficient time in order to make the necessary amendments:

- decisions taken by the Community to amend the Common Customs Tariff, and

- to suspend or reintroduce duties and any decision conceming tariff quotas or ceilings.

\section{Agriculture and Processed Agricultural Products}

The customs union covers "products other than agricultural products" (Art. 2). Therefore, agricultural products are excluded and only industrial goods may benefit from the customs union.

Given the differences in the agricultural policies of both sides, the Parties did not see fit to embark on the free movement of agricultural products. Thus, the customs union covers only industrial products.

The Association Agreement provided that "the Association shall likewise extend to agriculture and trade in agricultural products, in accordance with special rules which shall take into account the Common Agricultural Policy of the Community." Furthermore, "agricultural products" meant the products listed in Annex II of the Treaty of Rome (Art. 11).

Decision 1/95 affirmed 'the Parties' common objective to move towards the free movement of agricultural products" but noted that "an additional period is required" to establish the conditions necessary to achieve this free movement (Art. 24). Thus, Turkey and the Community shall progressively improve the preferential arrangements which they grant each other for their trade in agricultural products.

What about processed agricultural products? They are not completely industrial products but contain an important "agricultural component".

Although customs duties and measures having equivalent effect have been abolished, Turkey and the EC may apply "agricultural components" established in accordance with the Decision 1/95. 
How can we determine the so-called "agricultural component"? According to Article 19, agricultural components may be obtained by "adding together the quantities of basic agricultural products considered to have been used for the manufacture of the goods in question", multiplied by the "basic amount" corresponding to eaach of these basic agricultural products.

The Community shall apply to Turkey the same specific duties that represent the "agricultural component" applicable to third countries. Turkey, too, shall apply the "agricultural component" to imports from the Community. There are a number of annexes to the Decision 1/95 explaining the procedure concerning processed agricultural goods.

\section{Competition Law : The Adaption of Turkish Law to the EC Model}

With the 1963 Association Agreement, Turkey and the EC recognized that the Treaty of Rome provisions on competition, taxation and the approximation of laws "must be made applicable in their relations within the Association." (Art. 15).

According to the Additional Protocol of 1970, the provisions of the Treaty of Rome on competition (Articles 85, 86, 90, 92) were going to be applied. In order to do so, the Council of Association was to adopt the conditions and rules for the application of the competition principles laid down in those articles by 1979. But such a decision was not taken.

Decision 1/95 provided the "competition rules for the customs union" in Articles 32-38.

Article 32 of the Decision 1/95 is a verbatim copy of Article 85 of the Treaty of Rome. The only difference is in the first sentence where it is stated that: "the following shall be prohibited as incompatible with the proper functioning of the customs union..."; in the original text (Art. 85) this reads "the following shall be prohibited as incompatible with the common market..."

Similarly, Article 33 of the Decision 1/95 is a copy of Article 86 of the Treaty of Rome where the phrase "common market" is replaced by "customs union".

Article 34 of the decision corresponds to Article 92 of the treaty where it is provided that "any aid granted by EC Member States or Turkey through state resources" is incompatible with the proper functioning of the customs union.

Since these provisions are copied from the relevant articles of the treaty, Article 35 of the Decision 1/95 provided that "any practices contrany to Articles 32, 33, and 34 shall be assessed on the basis of criteria arising from the application of the rules 
of Articles 85, 86 and 92 of the Treaty establishing the European Community and its secondary legislation."

There is another duty imposed on the Association Council. By 1998, the Council shall adopt by decision the necessary rules for the implementation of these articles concerning competition (Art. 37). Until these rules are adopted, the authorities of both sides shall rule on the "admissibility" of agreements, decisions and concerted practices and on the abuse of the dominant position in accordance with Articles 32 and 33.

If the Community or Turkey considers that a particular practice is incompatible with the competition rules but is not adequately dealt with under the implementing rules (which will be adopted by the Association Council) it may take "appropriate measures" after consulting the Customs Union Joint Committee (Art. 38).

This was not enough and it was provided that Turkey should have a "Competjtion Law" (Art. $39 \S 2$ (a)). Thus, before the entry into force of the customs union, Turkey should have adopted a law which would prohibit behaviours of undertakings under the conditions laid down in Articles 85 and 86 of the Treaty.

It was also required that before 1996 Turkey must "establish a "competition authority" which shall apply these rules and principles effectively."

The Decision 1/95 imposes a lot of requirements on Turkey which, it may be argued, fall outside the basic customs union structure. As the customs union arrangement is considered only a transitional or temporary measure which should lead to full membership, the requirement of a national law at this stage may be understandable. However, we would like to note that requiring Turkey to have a national competition law is rather excessive as italy -being a full member, not just having a customs union- did not have a national competition law until 1990. If a Member State had no national competition law for more than thirty years, then was not ittoo much to ask of Turkey to have national legislation on competition when it was only completing a customs union, not being a Member State? Furthermore, all the Member States' national legislation on competition varied greatly both in structure and in detail. Besides, if an agreement having a prohibiting effect on the Community were to be discovered, even if the agreement was made outside the EC (by foreigners who exercise no activities in the Community) it has long been held that the Commission would have extraterritorial competence. Therefore, even if there were no national legislation, Community competition laws could be applied. In any case, these provisions were included in Decision 1/95.

Turkey passed a Law on Competition in December 1994 which is also based on the competition articles of the Treaty of Rome. The Competition Board (Rekabet Kurulu) which will be administering this law has been formed. 


\section{Anti-dumping and other Trade Defence Instruments}

In a customs union, allegations of dumping is inconceivable. It was expected that with the completion of the customs union the Community allegations for dumping would be eliminated. Decision 1/95 has four articles in a special section entitled "Trade Defence Instruments.".

The application of "trade defence instruments" will be subject to a review by the Association Council. When the Council determines that Turkey has implemented competition provisions, controls on state aids and other parts of the acquis communautaire which are related to the Internal Market and ensured their effective enforcement, the Council of Association may decide to suspend the application of these instruments (Art. 44). The aim is to provide a guarantee against unfair competition comparable to that existing inside the Internal Market.

The Additional Protocol of 1970, in its Article 47, envisaged a very active role for the Council of Association in dumping cases. Indeed, during the transitional period, the Council of Association was to address "recommendations" to the Party with whom such practices (dumping) originate for the purpose of putting an end to them, if it finds that dumping is actually being practiced. Therefore, any allegations of dumping must be made to the Association Council by one of the Contracting Parties. If the Council establishes that there is dumping, it will address recommendations to the Parties involved.

When the Council issues recommendations concerning the dumping practices, but the practice continues, then the injured Party may take "suitable protective measures" after notifying the Council of Association.

If the interests of the injured Party call for immediate action, then it may introduce "interim measures of protection", i.e. provisional anti-dumping duties, after informing the Council. These "interim" measures may remain in force for up to three months. The Council may, at any time, decide that such protective measures shall be suspended pending the issue of the Council recommendations.

Decision 1/95, which marks the establishment of a customs union, refers back to Article 47 of the Association Agreement and stipulates that "the modalities of implementation of anti-dumping measures" explained in Article 47 (which was applicable only during the transitional period) "remain in force" when the customs union is achieved. This is of course contradictory and we expect that the Association Council will in one of its future meetings suspend the application of these instruments.

It is also contradictory for the following reasons: whereas Decision 1/95 "concerning the rules for implementing the final phase of the customs union" refers to Article 47 of the Additional Protocol which clearly had a limited period of application 
("during the period of twenty-two years", 1973-1995) but now, as far as the modalities of implementation of anti-dumping measures set out in Article 47 of the Additional Protocol are concerned, has been declared to "remain in force", the same decision stipulates that "the consultation and decision-making procedures" (provided in Section II of Chapter V) shall not apply to trade defence measures taken by either Party?.

The aim of Article 47 of the Additional Protocol was of course to settle the disputes concerning dumping allegations within the Council of Association through consultations; this was totally disregarded by the Community authorities during the very period for which it was specifically designed. Now, after the completion of the customs union where allegations of dumping should not be entertained, Decision 1/95 Article 46 not only declares that "modalities of implementation of anti-dumping measures of Article 47" remain in force but goes one step further and excludes the "consultation and decision-making procedures" referred to in Section II of Chapter V of Decision 1/95.

Through a series of laws, regulations and decrees for adapting the Turkish legal system to the European Community, Turkey has already aligned her rules on state aids, incentives, competition and the like and therefore, in principle, it should be expected that the Council take a decision for the suspension of provisions on trade defence instruments. However, safeguard clauses will remain in force.

\section{Taxation}

Decision 1/95 of the Association Council repeats these provisions in Association Agreement Article 16 and Additional Protocal Article 44 on indirect taxation (Art. 50). In terms of direct taxation the following principles are stipulated: no provision of the Decision $1 / 95$ shall have the effect of extending the fiscal advantages granted by either Party in any international agreement or arrangement by which it is bound. Both Turkey and the EC will be able to take any measure aimed at preventing the avoidance or evasion of taxes. Furthermore, both Turkey and the EC could apply the relevant provisions of their tax legislation to taxpayers whose position as regards place or residence is not identical.

7 Probably the Community felt the need to make a statement in order to avoid this contradiction. In deed, in a declaration by the Community, it was stated that "the Commission, without prejudice to the position of the Council, in the exercise of its responsibilities for anti-dumping and safeguard measures, will offer information to Turkay before the initiation of proceedings." According to this statement attached to the Decision 1/95, "appropriate modalities of application of Article 47 will be sel out jointly before the entry into force of this Decision", i.e. 1.1.1996, but we have no information which would indicate that such modalities were set up. In fact, the Community has been so generous (!) by declaring the following: "Furthermore, the Community will give, on a case by case basis, where appropriate, a clear preference to price undertakings rather than duties in order to conclude anti-dumping cases where injury is found." We believe that in a customs union the application of anti-dumping provisions is totally unjustified and it should be abandoned. 


\section{Intellectual, Industrial and Commercial Property Rights}

Another area of regulation where voluminous legislation was adopted and international conventions, protocols and agreements ratified by the Parliament, is intellectual, industrial and commercial property rights.

Article 31 of the Association Council Decision 1/95 was allocated to this subject where both the Community and Turkey confirmed the importance they attached "to ensuring adequate and effective protection and enforcement of intellectual, industrial and commercial property rights." According to this opinion, the customs union could function properly only if "equivalent levels of effective protection of intellectual property rights" were provided in both constituent parts of the customs union. Accordingly, the Parties undertook to meet the obligations set out in Annex 8 of the Decision 1/95 (Art. 31 §). Naturally, although reference was made to both of the Parties, it was Turkey that was going to implement all these provisions as the Community and Member States had already adopted these texts. However, many countries, which may be referred to as Turkey's competitors in international markets, consistently refused adopting such legislation or conventions, which would further hamper the competitivity of Turkish industry.

Again, it was Turkey that undertook to change the legal system in this area in an overwhelmingly extensive manner, in order to complete the process of the customs union. Annex 8 "On Protection of Intellectual, Industrial and Commercial Policy" which Turkey had to join, consisting of four full pages, nine articles but also listing many international conventions and agreements (all of which contain extensive provisions), in addition to extensive national laws to be adopted, shows the dimension of the undertaking that Turkey has entered into.

\section{Institutions of the Association}

\section{The Council of Association}

The Ankara Agreement provides a machinery for the decision-making process and a procedure for the resolution of disputes. The main decision-making institution of the Association is the Council of Association.

Recent judgments of the Court of Justice of the EC underlined the importance of this institution. Indeed, according to the Court, the decisions of the Association Council under the Association Agreement between Turkey and the EC constitute "an integral part of the Community legal system." In the Sevince Case ${ }^{8}$, the European Court of Justice held that "acts (decisions) adopted by the Association Council 


\section{can be directly effective in the Community if they comply with the same re- quirements as apply to the Association Agreement."}

The Council of Association consists of members of the governments of the Member States and members of the Council and of the Commission of the Community on one side and of members of the Turkish Government on the other (Art. 23). However, to redress the balance of numbers, it was agreed that the decisions must be taken unanimously. This rule reflects the bilateral and equal character of the Association.

Article $22 \S 1$ of the Ankara Agreement empowers the Council of Association to take decisions "in order to attain the objectives of this agreement [...] in the cases provided for therein", i.e. the agreement. Therefore, one may assume that the Council of Association may take decisions only in the cases provided for in the agreement. Thus, both the Association Agreement and the Additional Protocol contain many articles which impose a duty on the Council to take necessary measures for the implementation of the agreement covering a range of areas from customs arrangements to agriculture. (These include measures concerning the free movement of agricultural products, social questions like the free movement of workers, social policies, the freedom of establishment, the free movement of services, the extension of the Community transport policy to Turkey, the alignment of economic policies, etc.).

\section{The Committee of Association}

According to Article $24 \S 3$ of the Agreement, "the Council of Association may decide to set up committees to assist in the performance of its tasks, and in particular a committee to ensure the continuing cooperation necessary for the proper functioning of the agreement." In order to ensure the necessary cooperation between sessions of the Council, an Association Committee was established by a Decision of the Council of Association (Decision 3/64).

The Association Committee assists the Council in the fulfilment of its tasks: prepares for its proceedings and examines all the questions which are referred to it for

9 However, the powers of the Council of Association is not limited only to those issues which are specifically mentioned in the agreement or the protocol. In the course of the implementation of the Association arrangement, the "attainment of an objective of this agreement" may call for a "joint action by the Contracting Parties" but the requisite powers were not granted in the Association Agreement. Even in such cases where the agreement does not authorize the Association Council to take joint action, but the attainment of an objective of the Association requires such a measure, then the Council of Association, according to Article $22 \S 3$ "shall adopt appropriate decisions." It is clear that the Contracting Parties in adopting this provision were specifically "guided by" Article 235 of the Trealy of Rome which authorizes the Council to take the "appropriate measures" according to the Community decision-making procedure, even if "the Treaty has not provided the necessary powers". "if action by the Community should prove necessary to attain, in the course of the operation of the Common Market, one of the objectives of the Community." 
this purpose. Based in Brussels, the Committee meets at ministerial level "at least once every six months unless there is a decision to the contrary." Moreover, the Council of Association can decide on the creation of any other committee able to assist it in its tasks. As the Council is authorized to set up committees especially "40 ensure the continuing cooperation necessary for the proper functioning of the agreement", Decision 1/95 of March 6, 1995 established an EC-Turkey Customs Union Joint Committee which "shall carry out an exchange of views and in formation, formulate recommendations to the Association Council and deliver opinions with a view to ensuring the proper functioning of the customs union" (Art. 52). This Joint Committee shall meet at least once a month. However, it may be called for a special meeting should the need arise.

The institutional structure and the committees established under the Association Council need an in-depth study. Participation of Turkish experts "in the work of a number of technical committees which assist the European Commission in the exercise of its executive powers in areas of direct relevance to the functioning of the customs union" (Art. 60) is also an important matter which must be analysed.

\section{Consultation and Decision Procedures}

It is clear that Turkey is not only establishing a customs union with the European Community but is also adopting many of the common policies enforced by the Member States. Indeed, this situation may be qualified as "laking all the obligations" and "responsibilities" of a Member State without enjoying the benefits of membership, the most important of which is being able to take part in the institutions that make all the important decisions.

The Decision of the Association Council of March 6, 1996 (No. 1/95) contains seven long articles concerning "consultation and decision procedures". In areas of direct relevance to the operation of the customs union, Turkish legislation "shall be harmonized as far as possible with Community legislation" (Art. 54). "Areas of direct relevance to the operation of the customs union" has been defined in a very wide and comprehensive manner, including the following:

- commercial policy and agreements with third countries comprising a commercial dimension for industrial products;

- legislation on the abolition of technical barniers to trade in industrial products;

- competition;

- industrial and intellectual property law;

- customs legislation. 
Wherever new legislation is drafted by the European Commission in any of these areas which "have direct relevance to the operation of the customs union", the Commission shall "informally consult Turkish experts", together with experts from the Member States of the EC (Art. 55).

It remains to be seen how effective an "informal consultation" will be during the months to come. After formal consultations with the Member States' experts and "informal consultations" with Turkish experts, the Commission will transmit its proposal to the Council of the European Community where all the Member States are represented from working groups to COREPER and the Council of Ministers. As Turkey is not a member, the Commission "shall send copies thereof to Turkey", presumably for information purposes. However, before the actual decision of the Council of Ministers, the Community and Turkey may consult each other, upon mutual request, within the Customs Union Joint Committee (Art. 55). The drafters of this provision must not be satisfied with the consultation procedure described above as they added this following paragraph to the article concerned: the European Community and Turkey "shall cooperate in good faith during the information and consultation phase with a view to facilitating, at the end of the process, the decision most appropriate for the proper functioning of the customs union."

When the Community adopts legislation in those areas which have "direct relevance to the functioning of the customs union", Turkey will be immediately informed within the Customs Union Joint Committee, "to allow Turkey to adopt corresponding legislation which will ensure the proper functioning of the customs union." (Art. 56).

Where there may be problems for Turkey in adopting the corresponding legislation, the Customs Union Joint Committee "shall make every effort to find a mutually acceptable solution" in order to maintain a properly functioning customs union (Art. $56 \S 2)$.

Another contradictory provision is in Article 57 of the Decision 1/95 concerning the implementation of the customs union. The said provision mentions two opposing principles adopted in the decision: on the one hand it talks about the "principle of harmonization" which provides that Turkish legislation shall be harmonized as far as possible with Community legislation; on the other hand the same article mentions "Turkey's right [...] to amend legislation in areas of direct relevance to the functioning of the customs union." While Turkey has a right to amend legislation concerning the customs union -presumably the legislation adopted by the Community will be amended by Turkey before it is implemented or introduced into Turkish internal lawsuch a right to differ from the Community legislation depends on the approval of the Customs Union Joint Committee. This Committee has to conclude that "the amended legislation does not effect the proper functioning of the customs union." 
It is clear that an effective customs union needs complete harmonization of customs legislation which requires the participation of all the members of the customs union to take part in actual decision-making institutions. However a member of a customs union which is not a Member State of the EC is not represented in the institutions (Council, Commission, Parliament, Court of Justice and others). Therefore its chance of influencing the decisions is minimal. Since that country is not a full member, there is no direct effect or direct application of these texts in the country involved. Therefore, the legislation adopted by the Community has to be adopted by Turkey in order to introduce these texts into Turkish internal law. On the one hand, the decision recognizes "Turkey's right [...] to amend legislation in areas of direct relevance to the functioning of the customs union", on the other hand it limits this right to the effect that such "amended legislation does not effect the proper functioning of the customs union."

If, on the other hand, Turkey is contemplating new legislation in an area "of direct relevance to the functioning of the customs union", the Turkish Government shall "informally" seek the views of the Commission on the proposed legislation in question.

Furthermore, the wording of Article $57 \S 2$ is not in conformity with the regular diplomatic terminology: Turkey "shall informally seek the views of the Commission on the proposed legislation in question so that the Turkish legislator may take his decision in full knowledge of the consequences for the functioning of the customs union."

Once the proposed legislation has reached a sufficiently advanced stage of drafting, consultations will be held within the Customs Union Joint Committee. If such legislation is likely to disrupt the proper functioning of the customs union, the Customs Union Joint Committee shall try to find a mutually acceptable solution.

If discrepancies between Community and Turkish legislation cause or threaten to cause impairment of the free movement of goods or deflections of trade, the affected Party may take necessary protection measures and notify the Customs Union Joint Committee. Priority of the customs union. The Customs Union Joint Committee may decide whether to amend or abolish these measures.

For the judicial procedure for the settlement of disputes between Parties, the Council of Association Decision 1/95 provided an arbitration method which will be discussed below. At this juncture it is sufficient to note that the "protection measures" taken by the affected Party against such diserepancies in customs union legislation are included within the limited competence of the arbitration tribunal. 


\section{The Settlement of Disputes}

Whereas the legal disputes between Member States and Community institutions may be referred to the Court of Justice of the European Community, there is no provision in the Association Agreement whereby the Court would have automatic jurisdiction.

Should a dispute arise between Turkey and the EC relating to the application or interpretation of the Association Agreement (Additional Protocol or the Decisions of the Association Council), the Contracting Parties may bring the case to the Council of Association for a settlement (Art. 25). Complaints by private Parties or other organizations are implicitly excluded. Only Turkey, the Community and Member States of the Community may bring their complaints to the Council. Naturally, individuals or legal entities may bring their case to their respective governments of the Member State or of Turkey. It is interesting to note that a third State may not bring an action to the Association Council.

The Council may resolve the dispute by a decision which shall be binding on the part of the Parties concerned since each Party is required to take the measures necessary to comply with such decisions (Art. $25 \S 3$ ).

In cases where the Association Council cannot resolve the dispute (due to the fact that the decisions can be taken unanimously where both Turkey and the Community have one vote each) the Council may decide to submit the dispute to the Court of Justice of the EC or to any other existing court or tribunal. Naturally, the decision to submit a case to the European Court can only be taken unanimously. Therefore, when one of the Contracting Parties (the Community or Turkey) does not wish to bring the dispute to the Luxembourg Court or to any other judicial authority, the conflict will remain unresolved. This is another facet of the "institutional void" or deficiency in the Association which is so comprehensive and complex that a judicial mechanism will be required for an efficient interpretation and implementation of the customs union. It may be argued that the customs union is not in itself an end to this relationship and is introduced only as a pre-accession period which should lead to full membership in due course; therefore the present anomaly is only temporary.

The agreement provides another possibility for the settlement of disputes where the Council of Association cannot resolve the problem. Article $25 \S 4$ empowers the Council of Association to determine the detailed rules for "arbitration" or for "any other judicial procedure" to which the Contracting Parties may resort during the transitional and final stages of the Association. This is a special mechanism, as the associated country cannot be involved with the European Court betore accession. 
The Council of Association in its Decision $1 / 95$ (Customs Union) provided a special arbitration procedure with a very limited jurisdiction in terms of the types of conflicts which may be referred to for arbitration (Art. 61). Arbitration is only open in the following matters :

1) If discrepancies between Community and Turkish legislation or differences in their implementation in an area of direct relevance to the functioning of the customs union cause or threaten to cause impairment of the free movement of goods or deflections of trade and the affected Party considers that "immediate action" is required, it may itself take the necessary "protection measures". The measures taken by one of the Contracting Parties may be challenged by the other in the Arbitration Panel.

2) Safeguard measures taken in accordance with the agreement may also be brought to the Arbitration Panel ${ }^{10}$.

3) Rebalancing measures taken by either Party may also be referred to arbitration".

Where the disputes relate only to one of the three above-mentioned cases, a Contracting Party may bring the dispute to arbitration within six months of the date on which this procedure was initiated. Therefore, each Party must bring an action to the Arbitration Panel within six months.

The Arbitration Tribunal consists of three arbitrators. The two Parties to the dispute shall each appoint one arbitrator within thirty days. In such a procedure both Turkey and the Community will appoint one arbitrator each. The two arbitrators so designated shall nominate by joint agreement the third arbitrator who is referred to as the "umpire". The umpire may not be a national of either Turkey or the Community (or a Member State).

If arbitrators appointed by both Parties cannot agree within two months of their appointment, the umpire shall be chosen by them from a list of seven persons established by the Association Council.

The Arbitration Tribunal shall sit in Brussels and take its decisions by majority.

10 Article 60 of the Additional Protocol provides that "if serious disturbances" occur in a sector of the Turkish economy (or of the Community), or prejudice the external stability or adversely effect the economic situation in a region of Turkey (or the Community). Contracting Parties may take the "necessary protective measures". (Art. $60 \S 1$ for Turkey, Art. $61 \S 2$ for the Community).

11 According to Article 64 of the Decision 1/95, "if a safeguard or protection measure taken by a Contracting Party creates an imbalance between the rights and obligations under the -customs uniondecision", the other Contracting Party may take "rebalancing measures in respect of that Party". 


\section{Financial Cooperation and Free Movement of Workers : The Non-Implemented Provisions}

Whereas the establishment of a customs union between Turkey and the European Community has been achieved, the necessary support mechanism in terms of financial cooperation is still in limbo ${ }^{12}$.

In order to attain the objectives of the Association Agreement, Financial Protocols were made. The First Financial Protocol (1964) was for an amount of ECU 175 million for the financing of investment projects. Although this may seem to be a negligible amount today, at the time it played an important role. It should be noted that in 1964, Turkey's annual export figure was around 400 million dollars. Similarly, Second and Third Financial Protocols were signed and implemented until 1980 when the Fourth Financial Protocol was agreed. The total amount of Community funds to be allocated to Turkey within the framework of the Fourth Financial Protocol was ECU 600 million for a period of five years. Again, this figure may not impress the reader today but if we recall that in 1980 the yearly exports of Turkey were around the two billion dollar level, it is clear that the Fourth Financial Protocol provided a considerable amount of funds to Turkey. However, this Protocol has never been implemented and since 1980 Turkey has not benefited from any EC fund or credit. It must be added that after the Fourth Financial Protocol which was for a period of five years, Fitth and Sixth Financial Protocols should have been in progress covering the period up to 1996.

Indeed, whereas Turkey was reducing its customs walls towards Community products, the required Community support for the industrial restructuring in Turkey never materialized. Indeed, for a period of fifteen years, the Community failed to fulfill its obligations towards Turkey.

12 In fact, Turkey has not received any financial support from the Communily since 1980 when the Fourth Financial Protocol was adopled between the two Parties. From the beginning, the Association Agreement was regarded as "an association for the purposes of development" and "an association prior to accession". The preamble of the Ankara Agreement underlined this fact with the following statements :

- Determined to establish ever closer bonds between the Turkish people and the peoples brought logether in the European Economic Community;

- Resolved to ensure a continuous improvement in living conditions in Turkey, [...] through accelerated economic progress and the harmonious expansion of trade, and to reduce the disparity between the Turkish economy and the economles of the Member States of the Community:

- Mindful both of the special problems presented by the development of the Turkish economy and of the need to grant economic aid to Turkey during a given period;

- Recognizing that the support given by the European Economic Community to the efforts of the Turkish people to improve their standard of Iiving will facilitate the accession of Turkey to the Community at a later date;

[...] have decided to conclude an agreement establishing an Association... (OJ No. 217. 29.12.1964). 
Another important provision of the Association Agreement and Additional Protocol was the implementation of the free movement of workers in accordance with Articles 48,49 and 50 of the Treaty of Rome. Indeed, the free movement of workers was to be achieved gradually between 1976 and 1986 . The logic behind this arrangement was the following: whilst Turkey was opening up its markets to Community industrial products over a twenty-two year period, she was going to have some structural problems. Some industries were going to encounter difficulties and thus the process would result in unemployment. However, the loss of these jobs resulting from Community competition could be compensated by providing jobs for Turkish workers in Member States. Unfortunately, the provision for the free movement of workers was not implemented ${ }^{\text {t3 }}$ and the balance of rights and obligations of the two Contracting Parties in the Association Agreement was further disturbed to Turkey's loss. Not only were the financial protocols neglected, but also the free movement of workers could not be implemented. In spite of these negative influences Turkey continued to open up its markets to Community industrial products and by 1996 a customs union had been established.

Although the Commission in its opinion on Turkey's Request for Accession underlined "the importance of financial support to Turkey" in 1989 by stating that "Financial Cooperation should be revitalized by releasing the resources of the Fourth Financial Protocol" and adding that "the Community should further reflect on the possibility of unilaterally granting loans [...] for the financing of infrastructure projects of interest to both Turkey and the Community", no progress was made.

A close observer of Turkey-EC relations, in a lengthy analysis of the balance of rights and obligations of the two Parties, after underlining the importance of the release of the Fourth Financial Protocol, pointed out that there was a need to make "an offer to a direct follow-up by a new Financial Protocol or another measure which would contribute to the compensation for the negative economic consequences caused by the denial of freedom of movement" for workers ${ }^{14}$.

\section{E. Regional and Economic Effects of the Customs Union}

Economists point out that the liberalization of factor movements may entail the gravitation of productive factors from slow-growth areas to fast-growth areas, and this may in the short term cause economic imbalances and inequality which would naturally be unacceptable to Member States. Accordingly, the creation of a customs union profoundly affects the labor and capital markets in the countries concerned, 
and the integration of production factor markets affects the production of goods and thus trade.

As far as the standard neoclassical economic theory is concerned, it is of no real consequence why regional disparities emerge, since there are mechanisms in an economy which wil ensure that they will prove to be only a temporary phenomenon. Tomkins \& Twomey argue that "cumulative causation theories" provide "a strong theoretical rationale for widening regional prosperity. The basis of these theories lies in the recognition of the fact that because of the impact of differing levels of productivity or the existence of internal and external economies of scale, it is perfectly feasible that economic benefits begin to accumulate in particular regions of an economy and become self-perpetuating. In such circumstances, market forces may actually come to reinforce this development and contribute to unbalanced regional growth ${ }^{15}$.

It is clear that once the process of economic integration is in progress, it is likely that already existing problems of regional disparities will intensify. The productivity differentials will continue to exist and they will favor the technologically advanced firms of developed areas within the economic union.

Another important factor to be taken into consideration is this: economic integration may encourage the concentration of new industry and relocation of existing industry in certain areas of the union which give superior infrastructure, lower transport costs and availability of skilled labor. Thus, with the enlargement of the market and enhanced competition, the most efficient enterprises will expand by the integration process, while the less efficient will be driven out of the market. Consequently, the economic activity at the periphery of the economic union will be affected negatively and disproportionately from the effects of integration as the enterprises at the periphery are on the whole less efficient, with lower productivity than those at the developed center. Hitiris submits that in addition to these problems, there is always the possibility that common policies undertaken for the realization of integration objectives, may have profound and sometimes unforeseen regional effects." Therefore, it is clear that as a consequence of these reasons, the rates of growth in the developed centres will be higher than those in the less developed regions of the union.

On the one hand, the economic theories point out the advantages of primary forms of integration, namely of the goods markets and production markets, and argue that all partners may profit from the establishment of a customs union. Furthermore, the economic theories also underline that "the profit of integrated product Dearden (eds), London, 1992, p. 100.

16 Hitiris, T., European Community Economies, (2nd ed.), Harvester, 1991, p. 233. 
markets is enhanced if the internal movement of the production factors, that is to say movement of labor and capital is liberalized. To let markets function properly, a certain level of positive integration is needed."

Economists and politicians act upon the following assumption: competitive markets (efficiency) generate considerable inequality. Government and other institutions are then required to reduce this inequality by redistribution, even if it means some loss of efficiency ${ }^{17}$.

The European Community was created as a common market. The objective was to step up efficiency and stimulate economic growth by integrating the markets of goods and economic factors (Turkey-EC Association Agreement also provided the integration of the markets of goods and productive factors). That the ensuing structural changes in the EC implied some unacceptable consequences for certain sectors of the society was expected (like relocation of economic activities, changing composition of sectoral activity). The most vulnerable groups were concentrated in particular regions of the customs union. In short, regional problems are the disparities in the levels of income in rates of economic growth of output and employment, and in general in the levels of economic inequality between the geographic regions. Free competition does not tend to equalize factor returns across regions and therefore regional differences in economic development remain an important problem. Thus, market forces cannot be relied upon to produce the necessary degrees of inter-regional balance in economic growth. Hence, areas that were considered relatively prosperous before integration may turn into the backward regions of the union. Therefore, the costs and benefits of integration must be properly shared between the member countries and the regions of the economic union as a whole. To this end, the EC developed a number of instruments and policies which should be extended to Turkey being part of the same customs union. Indeed, the Community recognized that the problem of regional disparities between the richest and the poorest areas threatened to disrupt the convergence of economic performance inside the EC and to delay the progress towards integration. Various Community funds and common policies had been designed to function with regional problems among their objectives. These funds finance regional projects for the modernization of industry, investment for job creation, and training and retraining schemes in problem areas ${ }^{18}$.

17 According to Okun there is a trade-off between efficiency and equality. Okun, A., Equality and Efficiency: The Big Trade-Oft, Brookings, Washinglon, 1975.

18 For a detailed analysis of Community regional policies and related questions see, Molle, W., The Economics of European Integration - Theory, Practice, Policy, Dartmouth, 1990; McDonald, F. \& Dearden, S. (eds), European Economic Integration, Longman, 1990; EL-Agraa, A.M., The Economics of the European Community, (4th ed.), Harvester Wheatsheaf, 1994; Nielsen, J., Heinrich, H. \& Hansen, J., An Economic Analysis of the EC, McGraw Hill, 1992; Artis, M.J.\& Loe, N., The Economics of the EU, Oxford, 1994; Hitiris, T., op. cit., 1991. 
The Community decided that assistance will be provided where the GDP is below the national average or where there is dependence on agriculture or on a declining industry. Community regional funds are used in areas where there is a high rate of unemployment or net migration. Cases where Community policies, in particular free trade, had an adverse effect on Community funds will enter the picture.

"Completion of the Single Internal Market", according to a Commission paper, "renders inevitable that resources both of people and materials, and capital and investment, flow into areas of greatest economic advantage." Increasing openness of product and factor markets will generate gains, but it is not certain that they will be distributed equally among the regions of the Community. Therefore, it was admitted that the integration process may have adverse sectoral and regional effects on the problem regions. As a result, the Single European Act provided important increases in the funds allocated for regional development with particular emphasis on concentrating resources in the regions with per capita GDP of less than 75 percent of the Community average. These funds were ERDF, ESF, Guidance Section of EAGGF, etc.

Thus, all of Portugal, Ireland and Greece, parts of Spain, Italy and Eastern Germany, and the French overseas departments are listed as "first priority areas" because of their structural backwardness. This entitles them to funding of up to 75 percent from Community funds which were doubled by 1992 , increasing their share of the overall Community budget from 18 to 28 percent. Indeed, in February 1988, a decision was taken for the doubling in real terms of the resources of the three funds in the next five years.

The link established between the Internal Market and the doubling of resources ${ }^{19}$ through Structural Funds also meant an implicit recognition of the danger that the weaker regions of the Community could end up as net losers from further market integration.

For the five years period 1989-1993, a total of 60.3 billion ECU (in 1989 prices) was committed for spending through the three Structural Funds.

It may be of interest to students of Turkey-EC relations that by 1992, annual transfers through Structural Funds represented 3.5, 2.9, and 2.3 of GDP for Portugal, Greece and Ireland respectively $y^{20}$.

It should also be noted that the Commission called for a further substantial increase in the overall resources of the Structural Funds, which should raise ex-

19 De Witle, B., "The Reform of the European Regional Development Fund", in: Common Market Law Review, No. 23, 1986, pp. 419-440; Lowe, P., The Reform of the Community's Structural Funds", in: Common Market Law Review, No. 25, 1988, pp. 503-521. 
penditure to approximately 33.5 percent of the EC budget in 1997, compared to 27 percent in 1992.

On this matter, the Agreement on the European Economic Area (EEA) constitutes an important model as we recall that one of the demands of the less developed EC Member States in the EEA negotiations was that European Free Trade Association (EFTA) should assist in the development and structural adjustment of the poorest Community regions. (This was partly achieved through improved market access for certain agricultural products particularly important to the economies of these countries. Parallel to the EEA Agreement, a number of EFTA countries concluded bilateral agreements with the EC granting tariff and other concessions in the field of agriculture). The main solution was, however, a system of financial assistance provided by EFTA states. The financial mechanism was based on two different elements: grants and interest subsidies provided in connection with loans granted by the European Investment Bank. Among projects submitted by undertakings, special consideration was to be given to small and medium-sized enterprises. It was an interesting model as these EFTA countries were not becoming part of the customs union but were going to benefit from the free trade agreement. The less developed Member States of the EC requested these grants as a price for the opening of their markets to EFTA countries (Arts 115-117 and Protocol 38)21.

With the customs union, Turkey completely opened its markets to a much larger group of countries than the small EFTA states. The EU constitutes an economic power at least twenty times larger than the relevant EFTA countries at the time.

The Commission Opinion on Turkey's application for membership observed the following: "Progressive completion of the customs union will give the Community the opportunity to associate Turkey more closely within the operation of the Single Market, while taking into account the constraints imposed by the economic disparities between Turkey and the Community. This requires a strengthening of the machinery for agreeing concerted economic and social policies between the Turkish Government and the Community institutions. ${ }^{\text {22 }}$

\section{Conclusion: The Customs Union must Progress Continuously Towards Further Integration}

As pointed out elsewhere in this paper, the establishment of a customs union between Turkey and the European Community was not in itself the final target of the

21 Blanchet, T., Piipponen, B.R. \& Westman-Clement, M., The Agreement on the European Economic Area (EEA), A Guide to the Free Movement of Goods and Competition Rules No. 198, Oxford, 1994, pp. 18-19. 
Ankara Agreement. All of the four basic freedoms of movement of the Treaty of Rome were included in the Association Agreement. It was not only the establishment of a customs union (where both sides eliminate tariffs between themselves and establish a common tariff schedule on goods from outside countries) but the completion of a real common market, thereby removing all barriers to factor movements between Turkey and the EC, that was provided. So far, only one of the free movements has been achieved with the customs union. The Association Council is expected to start the implementation of other provisions of the agreement where both Turkey and the EC agree to be guided by the principles of the Treaty of Rome "for the purpose of abolishing restrictions on freedom of establishment between them" (Art. 13) and "for the purpose of abolishing restrictions on freedom to provide services" between Turkey and the EC. In fact, Article $41 \S 2$ of the Additional Protocol (1970) directs the Association Council to take necessary decisions to this effect: "The Council of Association shall, in accordance with [...] the Agreement of Association, determine the timetable and rules for the progressive abolition [...] of restrictions on freedom for establishment and on freedom to provide services."

Although the provision for the achievement of free movement of workers as provided in the agreement and the protocol could not be implemented because of unemployment and various social problems existing in some of the Member States, the suggestion put forward by Kramer" for a "measure which would contribute to the compensation for the negative economic consequences caused by the denial of freedom of movement" for workers should also be taken into account in future Association Council meetings in order to re-establish the equilibrium between the Community and Turkey.

"One argument for progressive integration" according to William Molle "... springs from political rather than economic theory. ${ }^{\text {n24 }}$ Molle explains why progressive integration is based on political theory in the following statement: "It is based principally on an analysis of the factors underlying the dynamics of integration, the outcome of which is that under the conditions prevailing in Western Europe, a free trade area and a customs union are unstable forms of cooperation, which can function only if progressing continuously towards further integration. When the progress stagnates, forces opposed to the Union's "rules of the game" may gain weight and combine with others to become a serious threat to the freedoms achieved. Disintegration could then be prevented only by further integration."

Therefore, in line with the areas referred to above, the Association Council should take the required decisions for the implementation of the principles already 
agreed on. Indeed, Article 6 of the Association Agreement directs the Association Council in the following terms: "To ensure the implementation of the progressive development of the Association, the Contracting Parties shall meet in a Council of Association which shall act within the powers conferred upon it by this agreement."

Furthermore, according to Article 7, "the Contracting Parties shall take all appropriate measures, whether general or particular, to ensure the fulfillment of the obligations arising from this agreement." Both the Community and Turkey "shall refrain from any measures liable to jeopardize the attainment of the objectives of the agreement." This "solidarity principle" is enshrined in Articie 7 of the Association Agreement, which, in identical terms to Article 5 of the EC Treaty, imposes a double duty upon the Parties, i.e. to take appropriate measures to ensure the fulfiliment of the obligations arising from the agreement and to refrain from taking any measures liable to jeopardize the attainment of the objectives of the agreement.

In this context, it must be stressed that the Association Agreement in Article 4 underlined the importance of "mutual and balanced obligations" of the Contracting Parties: "... the Contracting Parties shall, on the basis of mutual and balanced obligations: [...] align the economic policies of Turkey and the Community more closely in order to ensure the proper functioning of the Association and the progress of the joint measures which this requires."

Without the full implementation of financial cooperation provisions which would be needed for a successful implementation of a customs union between the Community and Turkey (in line with similar support systems available to Member States which were devised to correct the regional imbalances) and without the full implementation of the other free movement factors (free movement of services, right of establishment, free movement of workers or a compensation system for the negative economic consequences caused by the denial of freedom of movement), it cannot be said that the present state of affairs is based on mutual and balanced obligations.

The Association Council must take appropriate measures "in order to ensure the proper functioning of the Association and the progress of the joint measures which this requires", on the basis of mutual and balanced obligations. 